Haldane; "Is There an After-life ?", the Bishop of Birmingham ; "Can We Create Life ?", Prof. F. G. Donnan; "Is There Life on the Planets ?", Dr. H. Spencer Jones ; "Why Do I Dream ?", Prof. Cyril Burt; "Can We Harness the Atom ?", Prof. E. N. da C. Andrade; and "What Is My Conscience?", Prof. J. C. Flügel.

\section{New Research Laboratory of the L.M.S.}

ON December 10, Lord Rutherford opened the new L.M.S. Railway research laboratory at Derby in the presence of many well-known scientific workers and industrialists. Before the special train left St. Pancras, Pat Rutherford, grandson of Lord Rutherford, had the honour of naming the new Crewe-built engine of the special train. Sir Josiah Stamp first introduced him to the leading guests and then lifted him on to the running-plate of the engine. A purple cloth covered the name-plate. Pat pulled the cord to unveil the plate and called out, "I name this engine 'Lord Rutherford of Nelson'". We propose to print an account of the speeches made at the opening of the new laboratory at Derby in our next issue.

\section{The 200-inch Disk for the Mount Wilson Observatory}

According to the New York correspondent of The Times, the second two hundred inch pyrex glass disk which has been made at the Corning Works for the California Institute of Technology has been accepted as satisfactory by the scientific representatives of that institution. The disk has been annealing for twelve months, and it is expected that the process of grinding and figuring, which will take place at Pasadena, Cal., will occupy five years. There are said to be some flaws on the surface of the disk : these were caused through the floods of this summer, which shut off the heating apparatus for forty-eight hours, but they will be removed during the grinding process. Astronomers and others on the east of the Atlantic who have followed the not uneventful history of the manufacture of the mirror for the two hundred inch telescope with great interest, will be glad to hear that the present disk is satisfactory, and will wish their American colleagues a little luck, of which perhaps they have not yet had their share, in their delicate and long-continued operations on this large disk.

\section{Announcements}

THE honorary membership of the Royal Asiatic Society has been conferred upon Prof. Wilhelm Geiger, of the University of Munich, in recognition of his eminent services to Indian and Iranian philology.

THE following appointments have recently been made by the Secretary of State for the Colonies: Mr. J. C. Cater, to be assistant conservator of forests, Trinidad ; Mr. H. E. C. Lewys-Lloyd, stock inspector, Tanganyika, to be assistant live stock officer, Uganda.

Dr. Wilsur A. SAwyer has been appointed director of the Division of International Health of the Rockefeller Institute, New York.
ThE fourth International Congress of Cytology will be held in Copenhagen in 1936. The exact date has not yet been fixed, but the Congress will probably take place in August. Further information can be obtained from the General Secretary, Nassaustrasse 17, Berlin-Wilmersdorf.

THE Iron and Steel Institute is offering a number of grants from the research fund founded by $\mathrm{Mr}$. Andrew Carnegie in aid of metallurgical research. Candidates for grants must be less than thirty-five years of age. Applications should be made before January 10 to the Secretary, Iron and Steel Institute, 28 Victoria Street, London, S.W.1.

The first International Congress of Criminal Anthropology and Psychiatry will be held in Rome next April, when the following subjects will be discussed : etiology, diagnosis and prognosis of criminality in minors; prophylaxis of crime in relation to penal laws; fundamental conception of criminal biology; and prophylaxis of crime and criminal anthropology. Visits will be paid to the various Italian institutions for the prevention of criminality and re-education of delinquents in Rome, Naples, Orvieto and elsewhere. Further information can be obtained from the general secretary, Prof. B. di Tullio, via Giulia 52, Rome.

A PRACTICAL brochure entitled "Instructions for Collectors: No. 4-Insects", published by the British Museum (Natural History), has recently appeared in its eighth edition. It gives instructions, intended chiefly for persons travelling abroad, as regards the best methods for collecting insects and the essential apparatus. It is obtainable from the Museum or through booksellers, price $3 d$. (postage $1 d$ ).

Applications are invited for the following appointments, on or before the dates mentioned :

A part-time lecturer in practical mathematics in East Ham Technical College-The Secretary for Education. Town Hall, East Ham, E.6 (Dec. 17).

A scientific officer at the Building Research Station, Garston-The Establishment Officer, Department of Scientific and Industrial Research, 16 Old Queen Street, Westminster, S.W.1 (Dec. 19).

An assistant instructor in dairying to the Wilts County Council-The Clerk of the Council, County Offices, Trowbridge (Dec. 19).

Pharmacist-inspectors to the Pharmaceutical Society of Great Britain-The Secretary of the Society, 17 Bloomsbury Square, W.C.1 (Jan. 1).

A professor of mathematical physics in the Indian Institute of Science, Bangalore-The Director (Jan. 15).

A professor of physiology in the University of Queensland-The Secretary, Universities Bureau, 88A Gower Street, W.C.l (Jan. 25).

An assistant lecturer in mathematical physics in University College, Hull-The Registrar.

An assistant lecturer in chemistry in the Huddersfield Technical College--The Director of Education, Education Offices, Peel Street, Huddersfield. 